\title{
TEST OF AN ANIMAL DRAWN FIELD IMPLEMENT CART
}

\author{
Paolo Spugnoli, Alessandro Parenti, Piernicola Masella, Esteban Melani
}

\section{Introduction}

Animal draught use in agriculture concerns about $50 \%$ of worldwide cultivated soils, almost the $100 \%$ in developing countries [10] Draught animals are a major source of farm power in the drier rain-fed farms of sub-Saharan Africa especially among small-scale farmers; anyway in the tropical forest countries animal traction is not in use, because of bovine sickness and buffalo fear. Several researchers underlined the socioeconomic impacts of animal traction technology in the West African sub-region as well as in other developing countries $[3,6-8,12,16]$. Moreover, Starkey [12] indicated that in South Africa some commercial farmers as well as a substantial number of small scale farmers are using, or would like to use, draught animals on their farms. However, the current lack of specific implements for this type of mechanized agriculture significantly limits any animal use as alternative power [5].

Indeed, the in-use equipment comprises an antiquated range of implements that often are not suitable for the local conditions or for the animals use. Because of this, farmers experience frequent equipment breakdown and malfunction; the implements are rarely found in working order and usually need major repair. In industrialized countries traction animals have been almost completely eliminated apart from exceptional or ideological use. However, a recently renewed interest for environmentally safe techniques as practiced in biological agriculture has been seen; particularly in biodynamic agriculture - an ecological and sustainable farming system based on the "anthroposophical" teachings of Rudolf Steiner [14, 15], that includes many of the ideas of organic farming - the tractor use is limited, preferring animal labor force when possible. As a consequence, recent research in

Paper received 26.02.2007; accepted 10.01.2008

Prof. Ing. Paolo Spugnoli, Professore Ordinario; Prof. AlessanDro PARenti, Professore Associato; Dott. Piernicola Masella, Dottore di Ricerca; Ing. Esteban Melani, Dottore di Ricerca; DIAF, Università degli Studi di Firenze. the United Kingdom as well as in the United States of America has resulted in the development of a modern range of wheeled tool-carriers (often referred as hitchcarts), a multipurpose implement that can be used for various agricultural operations; this tool-carrier may have various designs and its use is in expansion in particular agricultural situations [2,9]. As reviewed by Joubert [5], two hitch-carts basic models are usually available: "the standard hitch-cart" and the "category one hitch-cart". The first is the simpler model generally designed with two wheel and a simple hitch both to allow transport and cultivation by pulling trailed implements. The second category comprises more sophisticated models with three or four wheels, a three point linkage system and a power take off (PTO); this cart is capable of using some small tractor mounted implements [5]. Examples of implement cart categories are available on the web [1].

Despite animal traction technology and hitch-carts utilization are gaining popularity among the above mentioned industrialized countries, Starkey $[11,13]$ stated the broad failure of this implements in the developing countries. It has been rejected because of its high cost, heavy weight and lack of maneuverability. However, the typical agricultural tractors and drawn implements used for large scale farming in developing countries are often large, powerful and not economically sustainable for the majority of small-scale farmers. For them, draught animals remain the main and best alternative power source as an intermediate technology to attain a sustainable situation and enhance the economic development.

This work aimed to assess the field performance of a handcrafted two wheel hitch cart equipped with a three point linkage and a ground wheel driven PTO. The cart is characterized by simplicity and constructive inexpensiveness, due to the use of second hand materials, by lightness and by high maneuverability. The limits within which the sole animal force could be used with PTO driven implements have also been evaluated. 


\section{Materials and methods}

In this work two series of trials were performed. The first series consists of preliminary traction tests performed with two horses (ploughing tests) and aimed to verify the available traction power of each animal so that to have indications about the feasibility of the use of the tested implement cart in terms of requested power. In the second series of trials the implement cart was tested by means of a tractor. In this way it was been possible to evaluate the cart performances in more controlled conditions than with the use of animals for pulling the cart.

The preliminary traction tests were performed using a single-furrow plough drawn by two horses (5 and 8 years old), of T.P.R. (Tiro Pesante Rapido, Fast Heavy Draught Horse) breed, weighing approximately $700 \mathrm{daN}$. Five tests were carried out, each one ploughing a furrow $20 \mathrm{~cm}$ deep by $25 \mathrm{~cm}$ wide and $50 \mathrm{~m}$ long. Draft was measured using a BLH strain gauge (model U3G1, Vishay Measurements Group $\mathrm{GmbH}$, Germany) load cell (response: $3 \mathrm{mV} / \mathrm{V}$; F.S.: $50 \mathrm{kN})$. The output of the load cell was connected with a data acquisition system based on a modular multichannel data logger (MCDR-M-128, Leane international, Italy) fitted to a laptop computer (MCDR128 acquisition software). The measuring system was calibrated before every test to avoid any possibility of error attributable to jerks. The same instrumentation was used for the hitch cart tests. In this case the two ends of the load cell were mounted through articulated eye joints between the hitch cart front bar and the rear hitch of a tractor. The tested hitch cart (Figure 1) is made up of an axle equipped with a differential gear box; on the axle a trapezoidal shaped chassis made with iron square section tubes was mounted.

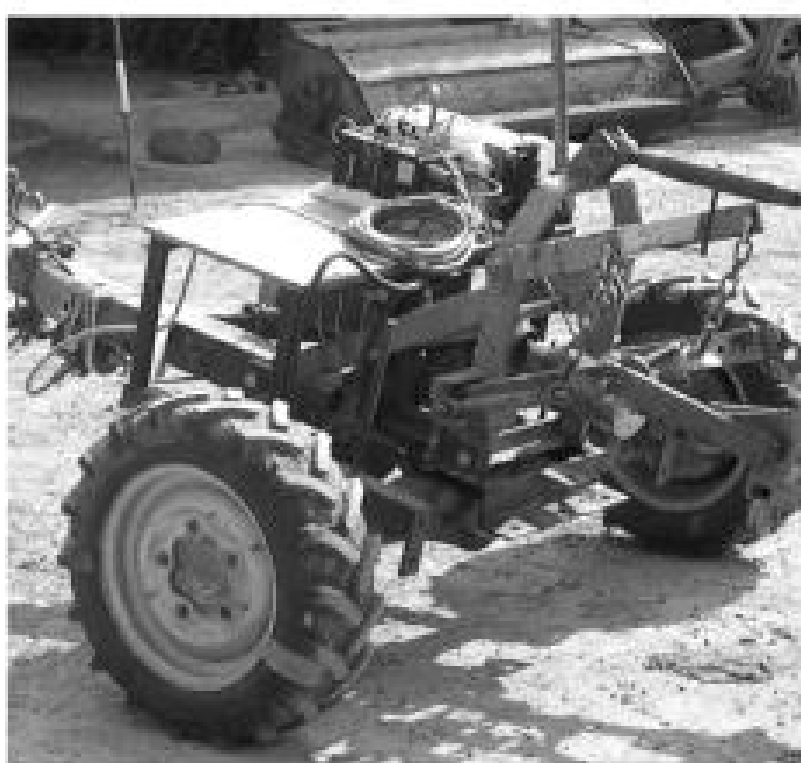

Fig. 1 - The tested hitch-cart.
The chassis supports part of the gearing transmission going from wheels to the PTO, to the harness coupling and to the driver's seat. On the whole, the cart has a track of $175 \mathrm{~cm}$, a length of $140 \mathrm{~cm}$ and a height of $68 \mathrm{~cm}$ (measured at driver's seat level). When empty, the weight is equivalent to $172 \mathrm{daN}$. The wheels fit pneumatic tires (measuring 6.50 - 14, width of $175 \mathrm{~mm}$ ). A characteristic of the cart is the PTO driven by the wheels: the PTO movement is obtained through a chain drive and the sprocket is directly moved by the differential. The PTO is connected to the transmission via a rigid joint (tooth clutch), which allows, using a specific lever, to transmit power when required for labor. The PTO may be unplugged when unnecessary (maneuvers, shifting etc.).

The overall transmission ratio is equivalent to 15.75. With a hypothetical forward speed of $1 \mathrm{~m}^{*} \mathrm{~s}^{-1}$ (average working horse speed), an equivalent value of about $573 \mathrm{~min}^{-1}$ is obtained from the PTO, which represents the theoretical number of revolutions without slippage. In order to evaluate the torque that could be supplied by the PTO, a disc brake has been applied to the PTO to simulate torque resistance given by driven implements. Finally, the hitch cart was equipped with a hydraulic three point hitch fitted with a manual operated hydraulic pump placed close to the driver seat.

In assessing the hitch cart's performances (second series of trials performed pulling the cart with a tractor as described before) 18 tests were undertaken, half on clay soil and half on turf soil, each on a drive of $50 \mathrm{~m}$. The tests were carried out varying the ballast $(80 ; 160 ; 240 ; 270 \mathrm{daN})$ mounted on the wheel axle and the torque applied at PTO (about from 3 to $23 \mathrm{~N}^{*} \mathrm{~m}$ ). Various parameters such us wheel slip, forward speed and draft were measured as described below. The fact of limiting mechanical measurement only to the draft, is motivated by the choice of using the simplest instruments easily applicable even in developing countries. Further, knowing the draft it was possible to derive the torque $\left(\mathrm{M}_{\mathrm{p}}\right)$ to the PTO (the direct measure of the torque is more difficult) by the relationship:

$$
\mathrm{F}_{\mathrm{t}}=\tau * \mathrm{M}_{\mathrm{p}} / \mathrm{R}+\mathrm{F}_{\mathrm{t} 0}
$$

where $\mathrm{Ft}$ is the draft force with different torque load on the PTO, $\mathrm{R}$ the wheel's loading radius and $\mathrm{F}_{\mathrm{t} 0}$ the draft force with zero torque load to the PTO. The term $\mathrm{F}_{\mathrm{t} 0}$ includes the resistance due to soil-wheel interaction and the resistance due to transmission loss. The draft force was measured by means of the same instrumentation previously described (first series of trials, traction preliminary tests).

Wheel slip was measured by counting in each trial the number of wheel revolutions on the test tract of $50 \mathrm{~m}$ length and using the relationship:

$$
\mathrm{S}=(\mathrm{N} 0-\mathrm{N} 1) / \mathrm{N} 0 * 100 \text {, }
$$

where $\mathrm{S}$ is the wheel slip (\%), N1 is the observed number of wheel revolutions and NO the theoretical number of wheel revolutions with no slip as derived from the wheel loading radius. The forward speed was measured by recording the time to travel $50 \mathrm{~m}$ 
distance. Two independent observations for each test were recorded and average was taken. Further, knowing wheel rotation speed $\left(\mathrm{n}_{\mathrm{w}}\right)$, as derived from the number of wheel revolution and the time to travel the test tract, the slippage $(\mathrm{S})$ and the transmission ratio $(\tau)$ between wheel and PTO, the rotation speed $\left(n_{p}\right)$ of the PTO may be immediately known.

The cart performances are expressed in terms of global efficiency $\left(\eta_{\mathrm{g}}\right)$ according to the relation $\eta_{\mathrm{g}}=\mathrm{W}_{\mathrm{p}} / \mathrm{W}_{\mathrm{t}}$, where $\mathrm{W}_{\mathrm{p}}$ is the power at the PTO and $\mathrm{W}_{\mathrm{t}}$ is the power supplied to the cart $\left(\mathrm{W}_{\mathrm{t}}=\mathrm{F}_{\mathrm{t}} * \mathrm{~V}\right.$, where $\mathrm{V}$ is the forward speed).

The slippage efficiency $\left(\eta_{S}\right)$ is given by the relation $\eta_{\mathrm{s}}=1-\mathrm{S}$, where $\mathrm{S}$ is the measured slip.

Knowing that:

$\eta_{\mathrm{g}}=\eta_{\mathrm{s}} * \eta_{\mathrm{m}} * \eta_{\mathrm{t}}$ (where $\eta_{\mathrm{t}}$ is the transmission efficiency and $\eta_{\mathrm{m}}$ is the motion efficiency), then

$\eta_{\mathrm{m}} * \eta_{\mathrm{t}}=\eta_{\mathrm{g}} / \eta_{\mathrm{s}}[17]$.

\section{Results}

Preliminary traction test results are shown in Table 1. Each test gives the measured forward speed and draft, plus the mean and standard deviation of both parameters.

As shown in the table, approximately the same forward speed was maintained in each test, while a strong variation was recorded in the draft force. This last evidence was probably due to the difficulty in maintaining a steady plough depth without stabilizing wheels. However, according to what reported in literature [4], draft varied between $163 \mathrm{daN}$ and $207 \mathrm{daN}$ with a mean value of about $176 \mathrm{daN}$. Referring to this last value, the mean power developed by two horses is equivalent to $1.763 \mathrm{~kW}$ ( $882 \mathrm{~W}$ per horse). Bearing in mind that each horse used in this experiment weighs about $700 \mathrm{daN}$, the resulting power/weight ratio is of $1.3 \mathrm{~W}^{*} \mathrm{daN}^{-1}$. As a good draught horse weight at about $900 \mathrm{daN}$, the correspondent available power may be considered of about $1 \mathrm{~kW}$ per horse.

The results of the hitch cart tests performed pulling the cart by a tractor are reported in Table 2 along with

\begin{tabular}{|ccr|}
\hline Test & $\begin{array}{c}\text { Mean forward speed } \\
\left(\mathrm{m}^{*} \mathrm{~s}^{-1}\right)\end{array}$ & $\begin{array}{c}\text { Draft } \\
(\mathrm{daN})\end{array}$ \\
\hline 1 & 1.0 & 163.3 \\
2 & 0.9 & 169.1 \\
3 & 1.1 & 207.7 \\
4 & 1.1 & 166.4 \\
5 & 1.0 & 175.0 \\
Average & 1.0 & 176.3 \\
Standard deviation & 0.1 & 18.1 \\
\hline
\end{tabular}

TABLE 1 - Forward speed and draft force in single furrow plough test drawn by couple of TPR horses.

the related performance parameters. All data in the table referred to a ballast of $80 \mathrm{daN}$. As shown in the table, slight slippage values were recorded in all the trials except that for the maximum PTO applied torque $(15.19 \mathrm{Nm}$ on clay soil); the $33 \%$ slip value is close to the possible upper limit. In this last case even the PTO rotation speed $\left(358 \mathrm{~min}^{-1}\right)$ was inadequate and borderline conditions can be seen in traction power requested, which is greater than that usually produced by a horse. Similar considerations are given for turf tests, where maximum PTO torque was $14 \mathrm{Nm}$, with a slippage of $15 \%$; this value, albeit acceptable on an efficiency level $\left(\eta_{\mathrm{g}}=0.6\right)$, corresponds to a too low PTO rotation speed $\left(367.5 \mathrm{~min}^{-1}\right)$.

Global efficiency $\left(\eta_{g}\right)$, slip efficiency $\left(\eta_{s}\right)$ and transmission per motion efficiency $\left(\eta_{\mathrm{m}} * \eta_{\mathrm{t}}\right)$ are reported in Figure 2 as a function of PTO torque $\left(\mathrm{M}_{\mathrm{p}}\right)$ both for clay and turf soil (ballast of $80 \mathrm{daN}$ ). It can be seen in both cases that the higher global efficiency occurred at a PTO torque level of about $10 \mathrm{Nm}$. With these conditions, draft force and traction power required varied around $800 \mathrm{~N}$ and $800 \mathrm{~W}$, optimizing horse power.

Table 3 gives the above same parameters values with varying ballast. Cases were selected according to acceptable working conditions in terms of efficiencies and PTO speed rotation. The data of draft $\left(\mathrm{F}_{t}\right)$ and wheel slip (S) indicated a direct relationship between them, i.e., the wheel slip increases with the increase in

\begin{tabular}{|c|c|c|c|c|c|c|c|c|c|c|c|c|}
\hline Soil & $\begin{array}{c}\text { Ballast } \\
(\mathrm{daN})\end{array}$ & $\begin{array}{c}\mathrm{V} \\
\left(\mathrm{m}^{*} \mathrm{~s}^{-1}\right)\end{array}$ & $\begin{array}{l}F_{t} \\
(N)\end{array}$ & $\begin{array}{l}\mathrm{F}_{\mathrm{t} 0} \\
(\mathrm{~N})\end{array}$ & $\begin{array}{c}\mathrm{M}_{\mathrm{p}} \\
\left(\mathrm{N}^{*} \mathrm{~m}\right)\end{array}$ & $\begin{array}{c}\mathrm{S} \\
(\%)\end{array}$ & $\begin{array}{c}\mathrm{n}_{\mathrm{p}} \\
\left(\min ^{-1}\right)\end{array}$ & $\begin{array}{l}\mathrm{W}_{\mathrm{t}} \\
(\mathrm{W})\end{array}$ & $\begin{array}{l}\mathrm{W}_{\mathrm{p}} \\
(\mathrm{W})\end{array}$ & $\eta_{\mathrm{g}}$ & $\eta_{\mathrm{s}}$ & $\eta_{\mathrm{m}}^{*} \eta^{*}$ \\
\hline clay & 80 & 1.11 & 386.51 & 235.32 & 2.78 & 0.02 & 559.00 & 429.46 & 162.88 & 0.38 & 0.98 & 0.39 \\
\hline clay & 80 & 0.94 & 654.03 & 235.32 & 7.71 & 0.03 & 472.50 & 613.16 & 381.28 & 0.62 & 0.97 & 0.64 \\
\hline clay & 80 & 1.00 & 785.88 & 235.32 & 10.14 & 0.06 & 488.25 & 785.88 & 518.05 & 0.66 & 0.94 & 0.70 \\
\hline clay & 80 & 1.03 & 1060.56 & 235.32 & 15.19 & 0.33 & 358.45 & 1097.13 & 570.08 & 0.52 & 0.67 & 0.78 \\
\hline turf & 80 & 0.86 & 493.84 & 320.69 & 3.19 & 0.03 & 432.00 & 423.29 & 144.15 & 0.34 & 0.97 & 0.35 \\
\hline turf & 80 & 1.20 & 752.62 & 320.69 & 7.95 & 0.04 & 595.35 & 903.15 & 495.58 & 0.55 & 0.96 & 0.57 \\
\hline turf & 80 & 0.94 & 861.22 & 320.69 & 9.95 & 0.07 & 450.35 & 807.39 & 469.14 & 0.58 & 0.93 & 0.63 \\
\hline turf & 80 & 0.83 & 1092.54 & 320.69 & 14.21 & 0.15 & 367.50 & 910.45 & 546.66 & 0.60 & 0.85 & 0.71 \\
\hline
\end{tabular}

TABLE 2 - Hitch cart performances on clay and turf soils according to the torque applied variation to PTO. 


\begin{tabular}{|c|c|c|c|c|c|c|c|c|c|c|c|c|}
\hline Soil & $\begin{array}{c}\text { Ballast } \\
(\mathrm{daN})\end{array}$ & $\begin{array}{c}\mathrm{V} \\
\left(\mathrm{m}^{*} \mathrm{~s}^{-1}\right)\end{array}$ & $\begin{array}{l}F_{t} \\
(N)\end{array}$ & $\begin{array}{l}\mathrm{F}_{\mathrm{t} 0} \\
(\mathrm{~N})\end{array}$ & $\begin{array}{c}\mathrm{M}_{\mathrm{p}} \\
\left(\mathrm{N}^{*} \mathrm{~m}\right)\end{array}$ & $\begin{array}{c}\mathrm{S} \\
(\%)\end{array}$ & $\begin{array}{c}\mathrm{n}_{\mathrm{p}} \\
\left(\min ^{-1}\right)\end{array}$ & $\begin{array}{r}W_{t} \\
(W)\end{array}$ & $\begin{array}{l}W_{p} \\
(W)\end{array}$ & $\eta_{\mathrm{g}}$ & $\eta_{\mathrm{s}}$ & $\eta_{\mathrm{m}} * \eta_{\mathrm{t}}$ \\
\hline clay & 80 & 1.00 & 785.88 & 235.32 & 10.14 & 0.06 & 488.25 & 785.88 & 518.05 & 0.66 & 0.94 & 0.70 \\
\hline clay & 160 & 0.97 & 1210.85 & 310.62 & 16.58 & 0.09 & 457.26 & 1171.79 & 793.30 & 0.68 & 0.91 & 0.74 \\
\hline clay & 240 & 0.88 & 1346.91 & 385.92 & 17.69 & 0.09 & 415.17 & 1183.49 & 768.90 & 0.65 & 0.91 & 0.71 \\
\hline clay & 270 & 1.01 & 1616.05 & 414.16 & 22.13 & 0.12 & 459.26 & 1624.93 & 1063.77 & 0.65 & 0.88 & 0.74 \\
\hline turf & 80 & 0.94 & 861.22 & 320.69 & 9.95 & 0.07 & 450.35 & 807.39 & 469.14 & 0.58 & 0.93 & 0.63 \\
\hline turf & 160 & 1.09 & 930.75 & 423.31 & 9.34 & 0.07 & 528.52 & 1014.52 & 516.85 & 0.51 & 0.93 & 0.55 \\
\hline turf & 240 & 1.16 & 1674.22 & 525.93 & 21.14 & 0.23 & 464.10 & 1934.66 & 1027.05 & 0.53 & 0.77 & 0.69 \\
\hline turf & 270 & 0.97 & 1727.74 & 564.41 & 21.42 & 0.16 & 421.47 & 1675.91 & 944.92 & 0.56 & 0.84 & 0.67 \\
\hline
\end{tabular}

TABLE 3 - Hitch cart performances on clay and turf soil according to the PTO torque with increasing ballast.
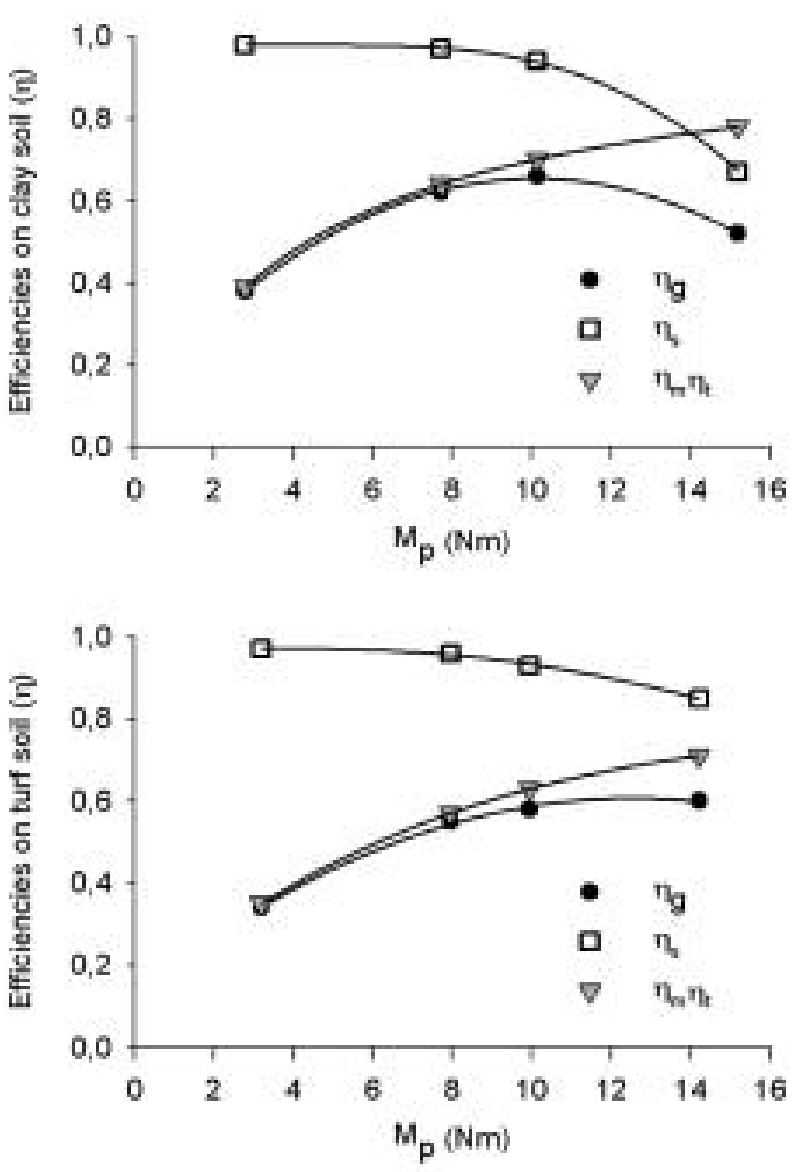

Fig. 2 - Hitch cart performances efficiencies as a function of PTO torque $(\mathrm{Mp})$ on clay and turf soils $\left(\eta_{\mathrm{g}}\right.$, global efficiency; $\eta_{\mathrm{s}}$, slip efficiency; $\eta_{\mathrm{m}} \eta_{\mathrm{t}}$, transmission per motion efficiency).

draft following the loaded ballast, albeit the slip variation was enough limited. Global efficiency was slightly influenced by ballast in both soil types, with a range of variation of 3 and $7 \%$ on clay and turf soils. Nevertheless, increasing ballast determined the highest draft force: from 785 to $1600 \mathrm{~N}$ on clay soil and from 860 to $1700 \mathrm{~N}$ on turf soil. With a ballast over $80 \mathrm{daN}$ a single horse traction capacity is not sufficient; in this case a couple should be used. Lowest global efficiency $(0.51)$ was given with a ballast of $160 \mathrm{daN}$ on turf. In this case a rather low torque is applied to PTO and a large part of the traction force is needed to overcome the transmission and motion resistances.

\section{Conclusion}

This work has considered the performance of a hitch cart equipped with PTO and able to transform the animal traction force and speed in PTO power through wheel motion. With the obtained results, performance is in keeping with the use of certain small farm implements, both of trailed and mounted type, made for small tractors and two-wheel tractors and noted for limited power requirements and low working speed. Power values required for these implements are sometimes higher than those recorded during tests. However, it must be underlined that animals can be considered as single power units. It is thus possible, within certain limits, to vary the number of animals to obtain the necessary traction force and power.

The tests undertaken have shown that the cart's performances were strongly affected by slippage, which occurs when increasing the PTO applied torque, depending on wheel soil adherence. Better wheel adherence can be obtained by increasing cart weight (ballasting) or improving wheel grip according to soil type. The testing has only considered cart ballast variation as it is easily applicable and very common. However the results have shown the limits of this solution in terms of increasing draft force and motion resistance. Advantages that could be gained via particular solutions, such as special grips tools or wheel cages, will be the object of future investigation.

\section{References}

[1] http://www.carthorsemachinery.com/index.html.

[2] Damerow G., Moore S., Heavy Horse World, (1997) 11(2), Printed by Stephens and George Ltd., Merthyr Tydfil in association with Caric Print Ltd., Clerwood, Corunna Main, Hants, United Kingdom.

[3] Gebregziabher S., Mouazen A.M., Van Brussel H., Ramon H., Nyssen J., Verplancke H., Behailu M., Deckers J., De Baerdemaeker J., Animal drawn tillage, the Ethiopian ard plough, maresha: A review, Soil \& Tillage Research (2006) 89, 129-143. 
[4] GEZA M., Harnessing techniques and work performance of draft horse in Ethiopia. In: Meeting the Challenges of Animal Traction. A Resource Book of the Animal Traction Network for Eastern Africa (ATNESA), (1999) Starkey, P., Kaumbutho, P. (Eds.), Intermediate Technology Publications, London.

[5] JOUBERT A.B.D., The horse-drawn hitch cart, in: Empowering Farmers with Animal Traction, Proceedings of the workshop of the Animal Traction Network for Eastern and Southern Africa -ATNESA, Mpumalanga, South Africa 20-24 September 1999, Kaumbutho P.G., Pearson R.A. and Simalenga T.E. eds., (2000) 213-218.

[6] PANIN A., Profitability assessment of animal traction investment: the case of northeastern Ghana. Proceedings of the 1988 Workshop on West Africa Animal Traction Network. In: Starkey P., N'diame F. (Eds.), (1988), 201-207.

[7] Pingali P., Bigot Y., Binswanger H., Agricultural mechanization and the evolution of framing systems in sub-saharan Africa. The John Hopkins University Press, Baltimore, (1987).

[8] Pingali P., From hand tillage to animal traction: causes and effects and the policy implications for Sub-Saharan African agriculture. International Rice Research Institute, Manila, Philippines. (1987) Network Paper No. 15.

[9] PINNey C., The Pintow Hitch Cart, Proceedings of a symposium organised by World Association for Transport Animal Welfare and Studies (TAWS) and the British Veterinary Association (Overseas Association), Hawshead Campus of the Royal Veterinary College (1996).

[10] RAMASWAMY N.S., Draught animal power: socioeconomic factors. Proceedings of an international workshop held at James Cook University, Townsville, Qld Australia, 10-16 July 1985. ACIAR Proceedings Series 10 (1985). In: Copland J.W., (Ed.), Draught animal power for production.

[11] Starkey P., Animal drawn wheeled toolcarriers: a case for caution, Appropriate Technology (1987) 14(1), 10-12.

[12] Starkey P., Animal Traction in South Africa, Empowering Rural Communities. Eds. by the Development of Southern Africa (DBSA) in cooperation with the South African Network of Animal Traction (SANAT).
[13] StARKey P., Perfected yet rejected: animaldrawn wheeled toolcarriers. (1988) Vieweg/GATE, GTZ, Eschborn, Federal Republic of Germany.

[14] STEINER R., Geisteswissenschaftliche Grundlagen zum Gedeihen der Landwirtschaft, (1924) R.S.V, Dornach.

[15] VereiJKen J.F.H.M., VAN Gelder T., BAARs T., Nature and landscape development on organic farms Agriculture, Ecosystems and Environment (1997) 63, 201-220.

[16] Williams T.O., Problems and prospects in the utilization of animal traction in semi-arid west Africa: evidence from Niger, Soil \& Tillage Research (1997) 42, 295-311.

[17] Zoli M., Spugnoli P., Ottimizzazione del sistema trattore-attrezzo: aspetti tecnici e riflessi economici, Accademia dei Georgofili, consiglio accademico atti (1989) (vii, xxxvi), 133.

\section{SUMMARY}

The field performance of a horse-drawn hitch cart equipped with a PTO system powered by the two cart ground wheels have been investigated. For this purpose field tests on clay and turf soil, with varying ballast and PTO torque, have been carried out pulling the cart by a tractor. Preliminary tests were aimed at assessing the traction capability of horse breed. These tests showed that the mean draught force given by two of these horses was $173 \mathrm{daN}$, average working speed was about $1 \mathrm{~m}^{*} \mathrm{~s}^{-1}$, resulting a mean draught power developed by each horse of about $0.86 \mathrm{~kW}$. The PTO cart system performance has shown that the torque has not exceeded $2.4 \mathrm{daN}^{*} \mathrm{~m}$, maximum draught or PTO power was $1.15 \mathrm{~kW}$, rotation speed just higher than $400 \mathrm{~min}^{-1}$, with mean efficiency of about $50 \%$. These values are consistent with horse performance and small haymaking, fertilizing, seeding and chemical application machine requirements.

Keywords: animal traction, horse-drawn hitch cart, PTO traction-powered efficiency. 
001_Spugnoli(505)_01 30-07-2008 9:37 Pagina 6

$\phi$ 